\title{
Effect of Plan of Nutrition on Growth of Female Buffalo Calves
}

\author{
Awadhesh Kumar', Satendra Kumar ${ }^{1}$, Ramjee Gupta ${ }^{2}$, \\ Manoj Kumar Singh ${ }^{1 *}$, and Deepak Singh ${ }^{1}$ \\ Department of Animal Husbandry and Dairying, C.S.A. University of Agri. and Tech., \\ Kanpur (208002), India \\ *Corresponding author
}

\begin{tabular}{|l|}
\hline Key w o r d s \\
Wheat straw, \\
Concentrates \\
mixture and buffalo \\
heifer
\end{tabular}

A B S T R A C T

The present experiment conducted at dairy farm during year 2017-18 at CSAUAT Kanpur. The rate of female buffalo calves is a major problem at dairy farm. Twelve female buffalo calves were selected for digestibility that on nutrition slid sample contain $86.50 \%$ DM, 20.10\% CP, $2.00 \%$ EE 15.5\% CF, 52.70\%NFE and $9.50 \%$ Ash. The average dry matter intake per $100 \mathrm{~kg}$ body weight was $(5.65,5.98$, $7.28 \mathrm{~kg}$ ) the digestibility coefficient of DM were recorded $(62.37,66.97,70.84)$ and digestibility coefficient of $\mathrm{CP}(73.67,74.51,78.36)$ and digestibility coefficient of CF $(64.29,65.20,66.37)$ and digestibility coefficient of EE (58.11, $61.47,62.35)$ and digestibility coefficient of NEE $(64.63,65.82,67.33)$ and digestibility coefficient of organic matter $(65.78,67.01,68.74)$. The average live weight in female buffalo calves were increased $(727.68,915.15,959.82)$ gm per day in group I, II and III respectively. The group III ${ }^{\text {rd }}$ was shown better performance in respect of growth parameters in other groups $\mathrm{I}^{\mathrm{ST}}$, II ${ }^{\mathrm{ND}}$ from the present study, it was apparent that the extra concentrate to be added in diet for proper development of growing calves $\mathrm{III}^{\mathrm{RD}}$ group were higher in growth . Digestibility coefficient of DM .CF, EE, NEE, OM, was also higher in group III ${ }^{\text {rd }}$.

\section{Introduction}

Livestock sector plays a crucial role in shaping the rural economy of India. It is a major continuous income generating activity for the rural households. Livestock rearing and crop husbandry are the two important components of mixed farming which influence agricultural economy leading to sustainable agriculture and are complementary to each other. On an average animal husbandry contributes about 27 per cent to agricultural gross domestic product (GDP) of the country, whereas, the contribution is much higher in hot semi-arid and arid region where conventional crop production is always a gamble due to uncertain and scanty rainfall. Livestock \& fisheries sector contribute over 4.11 per cent of total GDP of India (Economic Survey 2017-18). A symbiotic relationship exists between men, land and livestock. India is 
endowed with largest livestock population in the world.

The growth is such a universal phenomenon that it commonly incites little curiosity in the layman, but when the physiologist faces the question "what is growth"? The fertilization of a single cell starts multiplication and a differentiation which becomes highly varied in kind and rate in the differentiated cells yet remain coordinated and culminated in the adult. Schloss (1911) defines growth as a "Correlated increase in mass of the body in definite intervals of time in a way characteristic of species". The true growth involves an increase in the structural tissue such as muscle and bone of organs. It should be distinguished from the increase that results from fat deposition in the reserve tissues. Thus, growth is characterized by an increase in protein, mineral matter and water from the nutritional sage point it involves in addition a large intake of energy producing nutrients to support the growth process and an adequate supply of the various vitamins concerned is also required.

\section{Materials and Methods}

\section{Selection of calves}

The experiment was carried out for 8 weeks on buffalo female calves at Chandra Sekhar Azad University of Agriculture and technology dairy farm Kanpur. The twelve buffalo female calves have been selected approximately similar age of within two year and similar weight from herd these calves divided in to three groups consisting of four calves in each group. The female buffalo calves allotted to each group were strictly in random distribution on the basis of similarity in age. Conditions for weight similarity happened to be practically impossible, so variation within the weight was controlled through replication for eliminating much the response made. The following table represents the schedule of controlling the weight variation through replication for eliminating much the response to groups made the variation through replications.

\section{Recording observations}

When all the animals were accustomed for experimental conditions they were committed of each buffalo under resumed feeding of supplement the growth of each buffalo female calf was measured after each week in the morning under the following heads.

1. Live weight $(\mathrm{Kg})$

2. Heart girth $(\mathrm{cm})$

3. Length $(\mathrm{cm})$

\section{Method of feeding}

Out of three groups one group was fed according to Morrison's standard of feeding while the animal of other two groups were kept respectively, at a concentrate mixture intake of 20 per cent above the Morrison's standard $\left(\mathrm{T}_{3}\right)$ and 20 per cent below the Morrison's standard $\left(\mathrm{T}_{1}\right)$ attempt was made to keep the intake equal to Morrison's recommended average value for different body in all the groups. The concentrates were supplied in the morning of each day. The experiment was continued for 8 weeks all the precautions regarding feeding and sanitation were taken into consideration.

\section{Metabolism trial}

A metabolism trial trail of seven days duration was conducted to determine the digestibility coefficient of dry matter, crude protein, ether extract, crude fiber, nitrogen free extract, and organic matter. The animals were transferred to the metabolism cages for 10 days before the commencement of actual trial to acclimatize them in the situation. The faeces, urine, and residues were discarded two 
days before the actual collection period. During this period faeces and urine was collected separately and carefully weighed after twenty four hours. Each sample was taken mixed thoroughly and small amount was taken to the laboratory. Where suitable aliquot was weighed for analysis.

\section{Results and Discussion}

The chemical composition of green berseem, wheat straw and concentrate mixture are presented table no 1 .the variation in chemical composition of concentrate mixture in different proportion of deliberately was due to meet the nutritional requirement of the buffalo calves on the two dietary régimes. The DM, CP, CF, EE, and NFE, berseem was reported by Rajagopal and murty (1983).

\section{Plan of nutrition}

The twelve buffalo female calves were taken and divided into three equal groups $\left(\mathrm{T}_{1}, \mathrm{~T}_{2}\right.$, and $\mathrm{T}_{3}$ ) having four animals in each group. In group $T_{2}$, the animal were fed conventional feeding system in $T_{3}$ and $T_{1}$ were fed more than $20 \%$ and less than $20 \%$ recommended dose of concentrate respectively. Wheat straw was offered ad-lib and $4 \mathrm{~kg}$ berseem offered to each animal.

\section{Nutrient intake}

The dry matter consumption per day recorded was recorded from $3.73 \pm 0.11$ to $5.50 \pm 0.25$ $\mathrm{kg}$. There was no significant difference in dry matter consumption per day among the groups. Similar observation was recorded by Mishra et al., (1994). The dry matter consumption per $100 \mathrm{~kg}$ body weight was observed 5.23 $\pm 0.39,6.18 \pm 0.12$, and \pm 0.07 . There was significant difference among the groups. The dry matter intake when estimated on the basis of metabolic body size, it varied from $69.76 \pm 5.27, \quad 82.46 \pm 1.68$, and $102.16 \pm 1.03 \mathrm{~g}$ per day. Statistically significant difference was found in dry matter consumption per $100 \mathrm{~kg}$ metabolic body size between the various groups of animals. Similar observation was recorded by Chauhan et al., (2000). The intake of DCP was varied from $380 \pm 2.27,409 \pm 13.24$, and $484.50 \pm 2.90$ $\mathrm{g} /$ day and TDN were varied from $2.23 \pm 0.01$, $2.37 \pm 0.02$, and $2.61 \pm 0.02 \mathrm{~kg} /$ day.

Table.1 Randomization of treatment

\begin{tabular}{|l|c|c|c|c|}
\hline S.No. & Treatments & Ear No & Date of birth & Initial weight \\
\hline 1 & T1 & 30 & $20-09-2016$ & 63 \\
\hline 2 & T1 & 4 & $23-08-2016$ & 73 \\
\hline 3 & T1 & 36 & $05-01-2017$ & 74 \\
\hline 4 & T1 & 40 & $19-01-2017$ & 78 \\
\hline 5 & T2 & 3 & $15-02-2017$ & 64 \\
\hline 6 & T2 & 35 & $17-09-2016$ & 72 \\
\hline 7 & T2 & 69 & $13-7-2016$ & 74 \\
\hline 8 & T2 & 33 & $16-02-2017$ & 76 \\
\hline 9 & T3 & 34 & $26-10-2016$ & 68 \\
\hline 10 & T3 & 140 & $26-10-2016$ & 69 \\
\hline 11 & T3 & 43 & $21-4-2016$ & 75 \\
\hline 12 & T3 & 48 & $06-11-2016$ & 75 \\
\hline
\end{tabular}


Table.1 Chemical composition of ration fed to different groups

\begin{tabular}{|l|l|l|l|l|l|l|}
\hline Feed materials & $\begin{array}{l}\text { DM } \\
(\mathbf{\%})\end{array}$ & $\begin{array}{l}\text { CP } \\
(\mathbf{\%})\end{array}$ & $\begin{array}{l}\text { EE } \\
(\mathbf{\%})\end{array}$ & $\begin{array}{l}\text { CF } \\
(\mathbf{\%})\end{array}$ & $\begin{array}{l}\text { NFE } \\
(\mathbf{\%})\end{array}$ & $\begin{array}{l}\text { Total Ash } \\
(\%)\end{array}$ \\
\hline Wheat straw & 90.00 & 3.00 & 1.00 & 38.00 & 46.00 & 12.00 \\
\hline Berseem & 20.00 & 16.50 & 2.50 & 24.50 & 46.25 & 10.25 \\
\hline Concentrate & 90.00 & 20.00 & 1.80 & 15.60 & 51.10 & 11.50 \\
\hline
\end{tabular}

Table.2 Showing the average value at different proximate principal and Weight gain (gm) per day

\begin{tabular}{|c|c|c|c|}
\hline Sr. no. Particular & $T_{1}$ & $\mathbf{T}_{2}$ & $\mathbf{T}_{3}$ \\
\hline Dry matter intake $(\mathrm{kg})$ & $3.73 \pm 0.16$ & $4.41 \pm 0.12$ & $5.50 \pm 0.25$ \\
\hline Metabolic body size (gm) & $69.76 \pm 5.27$ & $82.46 \pm 1.68$ & $102.16 \pm 1.03$ \\
\hline $\begin{array}{l}\text { 3. Dry matter intake/ } 100 / \mathrm{kg} \text { ) } \\
\text { Metabolic body wt. }\end{array}$ & $5.65 \pm 0.21$ & $5.98 \pm 0.22$ & $7.28 \pm 0.34$ \\
\hline DCP intake (gm) & $380 \pm 2.27$ & $409 \pm 13.24$ & $484.50 \pm 2.90$ \\
\hline TDN intake (kg) & $2.23 \pm 0.01$ & $2.37 \pm 0.02$ & $2.61 \pm 0.002$ \\
\hline \multicolumn{4}{|l|}{ Nutrients digestibility } \\
\hline Crude fiber $(\%)$ & $64.29 \pm 0.13$ & $65.20 \pm 0.32$ & $66.37 \pm 0.17$ \\
\hline Dry matter(\%) & $62.37 \pm 1.56$ & $66.97 \pm 0.58$ & $70.84 \pm 0.35$, \\
\hline Crude protein $(\%)$ & $73.67 \pm 0.57$ & $74.51 \pm 1.75$ & $78.36 \pm 0.42$ \\
\hline 4. Ether extract $(\%)$ & $58.11 \pm 1.93$ & $61.47 \pm 0.61$ & $62.35 \pm 0.16$ \\
\hline 5. Nitrogen free extract $(\%)$ & $64.63 \pm 0.52$ & $65.82 \pm 0.18$ & $67.33 \pm 0.26$ \\
\hline 6. Organic matter $(\%)$ & $65.78 \pm 0.30$ & $67.01 \pm 0.27$ & $68.74 \pm 0.13$ \\
\hline 7. Weight gain $(\mathrm{gm})$ per day & $415.18 \pm 15.24$ & $470.53 \pm 13.70$ & $580.35 \pm 23.62$ \\
\hline
\end{tabular}

\section{Digestibility of nutrients}

The digestibility coefficient of dry matter in I, II, and III groups were $62.37^{ \pm} 1.56$, $66.97{ }^{ \pm} 0.58, \quad 70.84^{ \pm} 0.35$ per cent, respectively. The data on dry matter digestibility were statistically significant. The higher digestibility of dry matter was observed in III, group. Increased dry matter digestibility suggests that most protein in basal protein supplement becoming available to ruminal microbes did rapidly after consumption. Similar observations were also reported by Kumar and Thakur (2007) in murrah buffalo calves. The average digestibility of crude protein $73.67^{ \pm} 0.57$,
$74.51^{ \pm} 1.75,78.36^{ \pm} 0.42$ percent in I, II, and III, group, respectively. These data are statistically significant. The present study indicated that an increase in concentrate mixture in diets, results in increased digestibility of crude protein. The view of present finding was supported by work of Sarwar et al., (2010). In the present study a higher value for crude protein digestibility was observed in group III. This might be due to the presence of more $\mathrm{CP}$ in concentrate The average digestibility of ether extract 58.11 ${ }^{ \pm} 1.93,61.47^{ \pm} 0.61,62.35^{ \pm} 0.16$ percent in I, II, III, group, respectively. These data are statistically significant. The lower digestibility of ether extract in experimental 
group may be due to lower fat content in the ration of concentrate mixture. Similar observation was also recorded by Srwar et al., (2009). The average digestibility of crude fiber $64.29^{ \pm} 0.13, \quad 65.20^{ \pm} 0.32,66.37^{ \pm}{ }^{ \pm} 0.17$ percent in I, II, III, group respectively. These data are statistically significant. The analysis of data there was no significant difference found within group. The average digestibility of NFE $64.63^{ \pm} 0.52,65.82^{ \pm} 0.18,67.33^{ \pm} 0.26$ percent in I, II, III, group respectively. These data are statistically significant. The higher digestibility coefficient of NFE was recorded in group III. SIMILAR Observation were reported by Kundu et al., (2016).The average digestibility of organic matter $65.78^{ \pm} 0.30$, $67.01^{ \pm} 0.27,68.74^{ \pm} 0.13$ percent in I, II, III, group, respectively. These data are statistically significant. All groups differed significantly at $1 \%$ level of probability. Similar observation was reported by Saha et al., (1993).

The balance of nitrogen was positive in all the three groups. Nitrogen balance was $35.66^{ \pm} 1.63,44.81^{ \pm} 2.47$, and $39.02^{ \pm} 9.61$, g in group I, II, and III, respectively. But statistically this difference was not significant. Similar observation recorded by Paul et al., (1994) in cross breed higher. The rate of daily live weight gain during 56 days growth trial was $727.68 \AA_{48.76}$, $915.18^{ \pm} 27.99,959.82^{ \pm} 27.99 \mathrm{~g} /$ day in I, II and III, group, respectively, significantly higher growth rate was observed in group III, than the control group of animal. Increased body weight gains with increasing level of concentrate in ration. Similar observation reported by Kumar et al., (2018)

In conclusion, the present investigation "Effect of plan of nutrition on growth of female buffalo calves" was conducted during 2018 at dairy farm Chandra Sekhar University of Agriculture and Technology Kanpur. In the study 12 female buffalo calves of approximately similar age and weight were selected. These female buffalo calves were divided into three groups randomly. Each group was consisting of four calves, restricting to the similar age consideration. Out of three groups each group was fed according to Morrison's feeding standard except group III and I which were additionally given concentrate 20 per cent high and low, and group II, treated as control group and no feed concentrate was given. The DCP and TDN intake were calculated on the basis of body weight were kept at Morrison's standard for all groups. The duration of experiment was 8 weeks.

\section{References}

Chauhan, T. R., Sharma, N. D., Dahiya, S. S., Gupta, R., Arora, U., Lall, D. (2000). Effect of plane of nutrition on milk yield, composition and nutrient utilization in lactating buffaloes in their early lactation, Buffalo Journal 2000 Vol. 16(2): 215-221.

Kumar, R., Kar, M., Kumar, D., Singh, V., and Sihag, S. (2018). Effect of Rumen Protected Amino Acids and Fish Meal on Feed Conversion Ratio of Murrah Buffalo Heifers, International Journal of Current Microbiology and Applied Sciences, 7(03): (2018).

Kundu, S.S., Goutam, M.U., Sontakke, K., Sharma, V.K. (2016). Effect of energy and protein levels on nutrient. Journal of Tropical animal health and production utilization and their requirements in growing Murrah buffaloes, Journal of Tropical animal health and production April 2016, 48(4): 807-815.

Kumar, B. and Thakur, S (2007). Effect of supplementing bypass fat on the performance of buffalo calves, $n$. (Indian J. Anim. Nutr., 2007, 24(4): 
233-236.

Mishra, A.K., Singh, S.K. and Maurya, P. (1994). Conducted an experiment on crossbred calves to see the different of two different plans of nutrition on growth performance they noted there was no significant difference in intake of calf starter between groups. The total DM intake from birth to 3 months of age and $\mathrm{DM}$ intake $/ \mathrm{Kg}$. body weight gain did not differ between groups, Indian Veterinary Journal, 84(3): 651654.

Kundu, S.S., Goutam, M.U., Sontakke, K., Sharma, V.K. (2016). Effect of energy and protein levels on nutrients utilization and their requirements in growing Murrah buffaloes. Journal of Tropical animal health and production April 2016, 48(4): 807-815.

Sarwar, M., Khan, M.A., Nisa, M., Bhatti, M.A. and Shahzad, M.A. (2009) Nutritional Management for Buffalo
Production, Asian-Aust. J. Anim. Sci. Vol. 22(7): 1060 - 1068 July 2009.

Paul, S.S., Bhar, A.K. and Lamba, M. (2008)Double and triple cross in cattle Dehradoon farm Indian Journal of Animal Science, 78-6 661-665.

Singh, H., Grewal, R.S., Kaur, S., Kaur, J., Singh, C., Lamba, J.S. and Malhotra, P. (2018). Effect of Organic $\mathrm{Cu}$ and $\mathrm{Zn}$ on the Performance of Pre-Ruminant Buffalo Calves, Int.J.Curr.Microbiol. App.Sci (2018) 7(5): 763-769.

Sarwar .M. (2010) Growth of nine month old male buffalo calves as affected by different crude protein and energy concentrations, International seminar on tropical animal production.

Rajagopal, S. and Murty, V.N. (19983). Effect of feeding levels of concentrate nature ad-lib green berseem on nutrient utilization in lactating cows. Kerla J. Veterinary Sci., 14 (2):115-130

\section{How to cite this article:}

Awadhesh Kumar, Satendra Kumar, Ramjee Gupta, Manoj Kumar Singh and Deepak Singh. 2020. Effect of Plan of Nutrition on Growth of Female Buffalo Calves. Int.J.Curr.Microbiol.App.Sci. 9(03): 2307-2312. doi: https://doi.org/10.20546/ijcmas.2020.903.261 